\title{
24. Pb ISOTOPE RATIOS OF NORTH PACIFIC SEDIMENTS, SITES 881, 883, AND 884: IMPLICATIONS FOR SEDIMENT RECYCLING IN THE KAMCHATKAN ARC ${ }^{1}$
}

\author{
Annie B. Kersting ${ }^{2}$
}

\begin{abstract}
The $\mathrm{Pb}$ isotope ratios of 13 sediment samples, collected during Ocean Drilling Program Leg 145 at Sites 881, 883, and 884 in the North Pacific east of the Kamchatkan trench, were determined. The sediments were selected from continuously recovered cores and are representative of the range of sediment compositions recorded. The sediments analyzed are predominantly pelagic oozes, representing approximately $50 \mathrm{~m} . \mathrm{y}$. of depositional history, and have an age span from Pliocene to Eocene. $\mathrm{Pb}$ isotope covariations of all the samples are more radiogenic than Pacific mid-ocean ridge basalt.

These sediments provide the best analog for previously subducted sediments beneath the Kamchatkan arc. Previously analyzed basalts from Klyuchevskoy volcano, Kamchatka, have $\mathrm{Pb}$ isotope ratios that fall within the MORB field. The sediments analyzed in this study are significantly elevated in their $\mathrm{Pb}$ isotope composition to preclude their addition to the source of the Klyuchevskoy volcano. Sediments or sediment-derived fluids are not involved in the generation of Klyuchevskoy magmas, and thus are not required for arc magmagenesis.
\end{abstract}

\section{INTRODUCTION}

Determining which elemental components of the subducted material (altered oceanic crust, sediment, fluids) are recycled into the overlying mantle and ultimately into the arc crust vs. which are carried into the deep mantle is central to understanding global geochemical modeling, island-arc petrogenesis, and ultimately the differentiation of the crust and mantle (e.g., Kay, 1980; Hawkesworth et al., 1991; Plank and Langmuir, 1993). The sources involved in arc petrogenesis are chemically heterogeneous, and, as yet, no simple generalized model serves to explain the diverse body of data available from different island arcs (Arculus and Johnson, 1978).

Island-arc volcanic rocks have trace element and isotope characteristics that are distinct from mid-ocean ridge basalt (MORB). Island-arc basalts are characterized by enriched large-ion lithophile, light-rare-earth, and depleted high-field-strength element concentrations compared with MORB. Owing to the chemical distinctions between island-arc lavas and MORB, it has been recognized that island-arc basalts cannot result from simple partial melting of the depleted upper mantle (e.g., Coats, 1962; Perfit et al., 1980; Gill, 1981; Hawkesworth et al., 1991). Initially the source for island-arc magmas was thought to be the subducting slab (Coats, 1962; Armstrong, 1968; Marsh, 1982; Meyers et al., 1985), although it is now generally recognized that the major source of island-arc magmas is the mantle wedge (Gill, 1981; Arculus and Powell, 1986; Crawford et al., 1987) plus a metasomatic flux of either melt (e.g., Nicholls and Ringwood, 1973) or fluid (e.g., Tatsumi et al., 1991) from the subducted slab. The nature of this metasomatic flux (melted oceanic crust, fluids, or sediments) and its role in the genesis of arc magmas is not well understood.

The purpose of this study was to determine the $\mathrm{Pb}$ isotope ratios and assess the $\mathrm{Pb}$ isotope heterogeneity of sediments deposited proximal to the Kamchatkan arc. These data were examined in conjunction with published geochemical data on Klyuchevskoy volcano, Kamchatka (Arculus et al., 1994; Kersting and Arculus, 1994, in press), to assess the role of sediment subduction and recycling in island arcs. The composition of the oceanic sediments, altered oce-

\footnotetext{
${ }^{1}$ Rea, D.K., Basov, I.A., Scholl, D.W., and Allan, J.F. (Eds.), 1995. Proc. ODP, Sci. Results, 145: College Station, TX (Ocean Drilling Program).

${ }^{2}$ Earth Science Department and Institute of Geophysics and Planetary Physics, Lawrence Livermore National Laboratory, P.O. Box 808, L-202, Livermore, CA 94550 U.S.A.
}

anic crust, mantle wedge, and overlying lithosphere can be isotopically distinct, and thus, the application of isotope analysis offers the potential to quantify the recycling process occurring at island arcs. In general, the large difference in the concentration and isotope ratios of $\mathrm{Pb}$ between the mantle and oceanic sediments makes it a particularly sensitive tracer to the presence of sediment in the recycling process (Kay et al., 1978; Tatsumoto, 1978).

Oceanic sediments (carbonates, clays, and siliceous oozes) have a wide range in chemical composition, and the relative proportions and chemical composition of these sediments can vary greatly from one trench to another (Sun, 1980; Ben Othman et al., 1989; Lin, 1992; Plank and Langmuir, 1993). For the purposes of constraining the chemical mass fluxes in island arcs it is prudent to analyze sediments and island-arc volcanic rocks collected in close proximity. Sediment samples from Ocean Drilling Program (ODP) Leg 145 are the best analogs for sediments previously subducted beneath Kamchatka. The bulk composition of the sediments entering the trench can be estimated by the comparison of several different cores collected parallel to the arc. The cores collected during Leg 145 provide excellent coverage on the nature of the sediments east of the Kamchatkan trench. Sediment samples were selected from drill cores recovered at three of the seven sites $(881,883$, and 884) closest to the Kamchatkan arc (Fig. 1). Klyuchevskoy volcano was chosen, as it is well characterized and has erupted some of the most primitive basaltic magmas found in islandarc settings, thereby minimizing the effects of lithospheric involvement in magma generation.

\section{SEDIMENT INVOLVEMENT IN ISLAND-ARC MAGMAGENESIS}

Strong evidence for the subduction of sediments comes from geochemical examination of preserved high-pressure mineral assemblages of ancient sedimentary protoliths (Becker and Altherr, 1992; Davies et al., 1993; Pearson et al., 1993), isotope evaluation of islandarc and oceanic island volcanoes (e.g., Tatsumoto and Knight, 1969; Davidson, 1983; Morris and Hart, 1983; Ryan and Langmuir, 1988), and simple mass-balance arguments between the volume of sediment observed worldwide and the estimated regional sediment budgets (e.g., Gilluly et al., 1970; Hussong and Wipperman, 1981; von Huene and Scholl, 1991). Yet the extent and process by which sediments influence arc magmagenesis remains controversial. Support for the incorporation of sediments in the source of arc magmas comes in part from recent ${ }^{10} \mathrm{Be}$ isotope studies (e.g., Brown et al., 1982; Tera et al., 


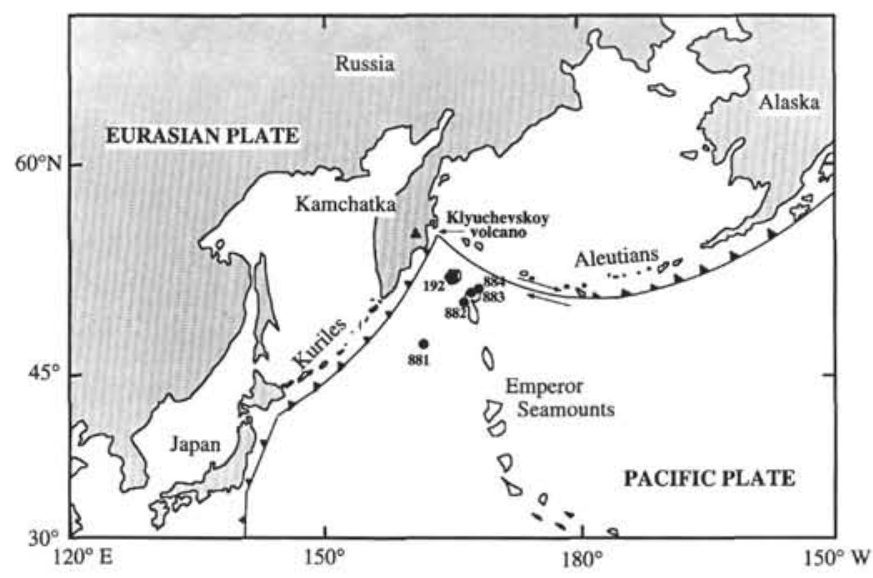

Figure 1. Location of Sites 881-884, DSDP Site 192, and Klyuchevskoy volcano.

1986; Morris and Tera, 1989). The presence of high concentrations of ${ }^{10} \mathrm{Be}$ in some unweathered, young arc lavas requires the involvement of oceanic sediments into the magma source, although the process by which $\mathrm{Be}$ is incorporated into the source magma is not well understood, nor is it clear why ${ }^{10} \mathrm{Be}$ isotope anomalies are found only in some island-arc lavas (e.g., Aleutians, Kuriles) and not others (e.g., Marianas, Japan, Kamchatka). The estimated amount of sediment incorporated into the source of island-arc magmas from a variety of different studies ranges from no sediment recycling (Oversby and Ewart, 1972; Meijer, 1976; Ito and Stern, 1985), to minor amounts on the order of 1\%-3\% (Kay et al., 1978; White and Dupré, 1986), to the suggestion of substantial sediment recycling (Armstrong, 1971). Woodhead and Fraser (1985) estimated that $70 \%$ of the $\mathrm{Pb}$ measured in Mariana arc rocks comes from subducted sediments. From a global study of active island arcs, Plank and Langmuir (1993) concluded that $20 \%$ of the element budget in subducted sediment is recycled. These estimates have profoundly different implications for long-term chemical recycling between the crust and the mantle.

The impetus for the research presented here stems in part from previous work on primitive Quaternary volcanic rocks from Klyuchevskoy, Kamchatka, in which we concluded from $\mathrm{Pb}$ isotope data that sediments are apparently not incorporated in the source of the Klyuchevskoy lavas and by extension not required for arc magmagenesis (Kersting and Arculus, in press). Klyuchevskoy volcano, Kamchatka, Russia, lies $250 \mathrm{~km}$ northwest of the intersection between the Aleutian transform fault-trench system and the Kurile-Kamchatka trench (Fig. 1). The depth to the Wadati-Benioff zone beneath Klyuchevskoy volcano is approximately $150 \mathrm{~km}$ (Jarrard, 1986).

The $\mathrm{Pb}$ and $\mathrm{Nd}$ isotope ratios of the Klyuchevskoy basalts plot within the MORB field, whereas the $\mathrm{Sr}$ isotope ratios are slightly more radiogenic than MORB (Arculus et al., 1994). In terms of Sr and $\mathrm{Nd}$, Klyuchevskoy is similar isotopically to the Aleutian, Kurile, and Mariana arcs. In contrast, the $\mathrm{Pb}$ isotope data are the least radiogenic island-arc lavas measured to date. Although the most consistent explanation for the above data is that sediments are not involved in the generation of the Klyuchevskoy magmas, it is necessary to further constrain this hypothesis by determining if (1) sediments entering the Kamchatkan trench contain appreciable amounts of $\mathrm{Pb}$, and (2) isotope ratios of the North Pacific sediments are distinguishable from MORB. The data presented here help determine if sediments subducted and incorporated into the mantle source have enough chemical leverage to raise the $\mathrm{Pb}$ isotope ratios of the Klyuchevskoy lavas so that they are distinguishable from Pacific MORB.

\section{SELECTION OF SAMPLES}

The 13 oceanic sediment samples chosen for $\mathrm{Pb}$ isotope analysis were selected from three continuous cores recovered at Sites 881,883 , and 884. Exact drill hole, core segment, depth interval, and age of each sample is listed in Table 1. The upper Pliocene to lower Eocene sediments analyzed represent approximately $50 \mathrm{~m} . \mathrm{y}$, of sediment depositional history. Figure 2 shows the general lithology, approximate age, and depth of the samples analyzed. The overwhelming majority of the sediments recovered from Sites 881-884 are siliceous oozes. Although the majority of sediments analyzed in this study are predominantly diatomaceous oozes, two claystone and two nannofossil chalk samples were also analyzed representing the major types of sediments deposited in the North Pacific between the Pliocene through Eocene. Samples were chosen in order to test the chemical and isotope variability of $\mathrm{Pb}(1)$ in the dominate sediment type (siliceous ooze) entering the trench, (2) over the entire chemical range of major sediments types recovered, and (3) over a large depositional interval.

\section{ANALYTICAL TECHNIQUES}

Sample preparation and isotope measurements were carried out in a Class 100 clean-room facility in Lawrence Livermore National Laboratory's Nuclear Chemistry Department. Samples were dried in a fume hood at $50^{\circ} \mathrm{C}$ in covered, Teflon vials. The dissolution of sediments was performed using a combination of concentrated Seastar $\mathrm{HF}, \mathrm{HNO}_{3}, \mathrm{HCl}$, and $\mathrm{HBr}$ acids. $\mathrm{Pb}$ separation was achieved using standard anion resin techniques. See Nimz et al. (1993) for further analytical details.

For mass-spectrometric analysis, $50-100 \mathrm{ng}$ of $\mathrm{Pb}$ sample was loaded in $1.5 \mathrm{NHNO}_{3}$ with phosphoric acid and ultrafine silica gel onto a single Rhenium filament. Isotope measurements were performed on a single-collector VG-354 mass spectrometer using a Faraday cup.

Procedural blanks routinely analyzed during the course of this study have 300 to $350 \mathrm{pg} \mathrm{Pb}$ per $100 \mathrm{mg}$ rock. These blank concentrations are low relative to the elemental amount of sample analyzed; therefore, no corrections based on blank concentrations were made to the measured isotope data. The measured $\mathrm{Pb}$ isotope ratios were corrected for fractionation relative to analyses of $\mathrm{Pb}$ standard, NBS981, analyzed under the same operating conditions as the geologic samples (Todt et al., 1984). The isotope fractionation correction applied was $0.84 \%$ damu.

\section{RESULTS AND DISCUSSION}

\section{Composition of North Pacific Sediments Parallel to the Kamchatkan Trench}

Recovery of continuously cored oceanic sediments from Sites 881 , 883 , and 884 provides excellent coverage on the lithology of the sediments deposited near the Kamchatkan trench. The sediments recovered from Sites 881 through 884 share similar stratigraphy, although Site 884 contains the most silt and clay (Rea, 1993). The majority of sediments deposited are siliceous oozes. The uppermost unit, upper Pliocene to Pleistocene, consists of siliciclastic and ash-rich diatomaceous oozes. Miocene to upper Pliocene sediments consist of nearly pure diatomaceous oozes. At Sites 882-884, located on the sides of the Detroit Seamount, Eocene to Oligocene calcareous sediments underlie the Miocene diatomaceous oozes. Further discussion of the stratigraphy can be found in this volume.

The only other sediments collected near the Kamchatkan arc are from Site 192, drilled during Leg 19. Site 192 is located on the summit of the Meiji Guyot, the northwesternmost seamount of the Emperor Seamount chain (Fig. 1). The stratigraphy of the $1044 \mathrm{mbsf}$ of sediment collected at Site 192 and Sites $881-884$ is similar. For further details on the lithology of sediments recovered from Site 192, see Scholl and Creager (1973). The similarity in lithology between Site 192 and Sites 881-884 further confirms the observation that the relative proportions and chemical composition of the sediments entering the entire Kamchatkan trench can be approximated by samples selected from cores taken from Sites 881,883 , and 884 . The average 
Table 1. Pb isotope ratios of selected North Pacific sediments, Sites 881, 883, and 884 .

\begin{tabular}{|c|c|c|c|c|c|c|c|}
\hline $\begin{array}{l}\text { Core, section, } \\
\text { interval }(\mathrm{cm})\end{array}$ & $\begin{array}{l}\text { Depth } \\
\text { (mbsf) }\end{array}$ & $\begin{array}{c}\text { Sample } \\
\text { description }\end{array}$ & $\begin{array}{c}\text { Estimated } \\
\text { epoch }\end{array}$ & ${ }^{200} \mathrm{~Pb} /{ }^{200} \mathrm{~Pb}$ & ${ }^{207} \mathrm{~Pb} /{ }^{204} \mathrm{~Pb}$ & ${ }^{208} \mathrm{~Pb} /{ }^{04} \mathrm{~Pb}$ & $\begin{array}{c}\mathrm{Pb}^{2} \\
(\mathrm{ppm})\end{array}$ \\
\hline \multicolumn{8}{|l|}{$145-881 \mathrm{C}-$} \\
\hline $18 X-1,39-40$ & 156.19 & Clayey diatom ooze & late Pliocene & 18.67 & 15.59 & 38.63 & 14 \\
\hline $18 \mathrm{X}-1.39-40^{b}$ & 156.19 & Clayey diatom ooze & late Pliocene & 18.67 & 15.61 & 38.68 & \\
\hline $23 \mathrm{X}-1,39-40$ & 200.00 & Diatom ooze & early Pliocene & 18.67 & 15.60 & 38.64 & $3^{\mathrm{e}}$ \\
\hline $27 X-1,39-40$ & 238.69 & Diatom ooze & early Pliocene & 18.65 & 15.63 & 38.73 & 7 \\
\hline $27 \mathrm{X}-1,39-40^{b}$ & 238.69 & Diatom ooze & early Pliocene & 18.65 & 15.63 & 38.71 & \\
\hline $30 \mathrm{X}-1,39-40$ & 267.59 & Diatom ooze & late Miocene & 18.64 & 15.62 & 38.67 & 10 \\
\hline $35 \times-1,39-40$ & 315.79 & Diatom ooze & late Miocene & 18.63 & 15.62 & 38.72 & 9 \\
\hline $36 \times-1,39-40$ & 325.49 & Diatom ooze & late Miocene & 18.64 & 15.64 & 38.75 & 13 \\
\hline $36 \mathrm{X}-5,39-40$ & 331.49 & Diatom ooze & late Miocene & 18.59 & 15.60 & 38.65 & 12 \\
\hline \multicolumn{8}{|l|}{ 145-883B- } \\
\hline $37 X-2,130-135$ & 342.50 & Diatom ooze & late Miocene & 18.78 & 15.58 & 38.55 & 11 \\
\hline $62 X-6,130-135$ & 588.30 & Diatom nannofossil ooze and diatom ooze & middle Miocene & 18.64 & 15.57 & 38.51 & \\
\hline $63 X-5,130-135$ & 598.30 & Diatom nannofossil ooze & early Miocene & 18.58 & 15.56 & 38.52 & 14 \\
\hline $84 X-1,70-71$ & 799.90 & Nannofossil chalk & early Eocene & 18.55 & 15.60 & 38.59 & \\
\hline \multicolumn{8}{|l|}{$145-884 \mathrm{~B}-$} \\
\hline $24 X-1,39-40$ & 199.79 & Diatom ooze & early Pliocene & 18.71 & 15.58 & 38.51 & \\
\hline $78 \times-4,39-40$ & 723.99 & Claystone & late Eocene & 18.51 & 15.59 & 38.48 & 22 \\
\hline $78 \times-4,39-40^{b}$ & 723.99 & Claystone & late Eocene & 18.51 & 15.59 & 38.49 & 22 \\
\hline $86 X-5,39-40$ & 802.79 & Nannofossil chalk & early Eocene & 18.51 & 15.59 & 38.53 & 2 \\
\hline
\end{tabular}

$\mathrm{Pb}$ concentrations were determined by isotope dilution.

"Duplicate analyses were performed from different aliquots of sample.

'Sample fizzed strongly during acid digestion. Sample probably contains some calcium carbonate. This might account for the seemingly low $\mathrm{Pb}$ concentration.

bulk chemistry of the sediments entering the Kamchatkan trench is dominated by siliceous ooze with minor amounts of silt, clay, and chalk.

\section{$\mathrm{Pb}$ Isotope Ratios of the North Pacific Sediments}

The $\mathrm{Pb}$ isotope ratios $\left({ }^{206} \mathrm{~Pb} /{ }^{004} \mathrm{~Pb}=18.51-18.78,{ }^{207} \mathrm{~Pb} /{ }^{204} \mathrm{~Pb}=\right.$ $\left.15.56-15.64,{ }^{208} \mathrm{~Pb} /{ }^{204} \mathrm{~Pb}=38.48-38.75\right)$ of 13 sediment samples are shown on Figure 3 and listed in Table 1. Other oceanic sediments collected in the northern Pacific are shown for comparison. The North Pacific sediments analyzed, which represent approximately $50 \mathrm{~m} . \mathrm{y}$. of sedimentary deposition, plot well above the Pacific MORB field. Compared to the large range in $\mathrm{Pb}$ isotope ratios published for other Pacific sediments, the sediments entering the Kamchatkan trench are fairly homogeneous over a 50-m.y. time interval.

The sediments analyzed in this study overlap with the four pelagic clay samples analyzed by Ben Othman et al. (1989) and some of the samples from McDermott and Hawkesworth (1991), but are less radiogenic than sediments collected near the Aleutians (Chow and Patterson, 1962; Sun, 1980). Although the sediments are less radiogenic than the average Pacific sediments, they plot well within the range of Pacific sediments previously analyzed.

Although the $\mathrm{Pb}$ concentrations of the different sediment types range from $2 \mathrm{ppm}$ (nannofossil chalk) to $22 \mathrm{ppm}$ (clay-rich sediment), there is no correlation between sediment type and $\mathrm{Pb}$ isotope ratio; nor is there a correlation between $\mathrm{Pb}$ concentration and $\mathrm{Pb}$ isotope ratio. The $\mathrm{Pb}$ concentration in the majority of the clays and pelagic oozes analyzed (7-22 ppm) are lower than the clays analyzed by Ben Othman et al. (1989) (31-63 ppm), but similar to the concentrations measured by Sun (1980) (9-17 ppm).

The $\mathrm{Pb}$ concentrations and isotope ratios measured on sediments from Sites 881,883 , and 884 are distinguishable from Pacific MORB. They have a homogeneous $\mathrm{Pb}$ isotope ratio significantly more radiogenic than Pacific MORB and $\mathrm{Pb}$ concentrations well above the MORB average ( 0.5-1 ppm; Hofmann et al., 1986).

\section{Role of Subducted Sediments in the Recycling Process Beneath the Kamchatkan Arc}

In general, oceanic sediments have higher ${ }^{207} \mathrm{~Pb} /{ }^{204} \mathrm{~Pb}$ and ${ }^{208} \mathrm{~Pb} /{ }^{204} \mathrm{~Pb}$ ratio for a given ${ }^{206} \mathrm{~Pb} /{ }^{204} \mathrm{~Pb}$ ratio, compared with MORB. The incorporation of even a small amount of sediment into the mantle wedge source would significantly affect the isotope ratio of the erupted mag-

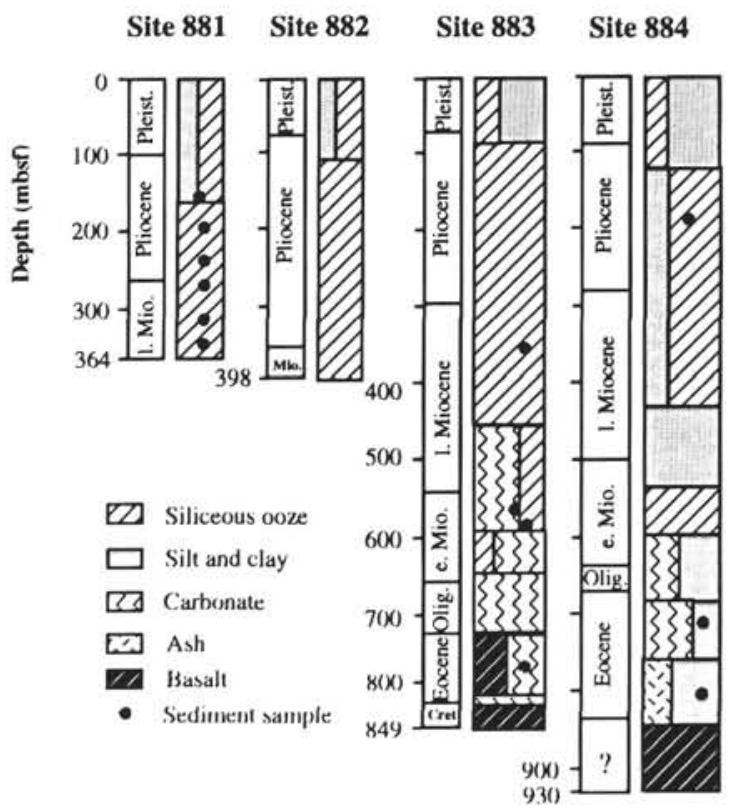

Figure 2. Generalized stratigraphic section of Sites 881-884. The approximate depth, lithology, and age is shown for each sediment sample analyzed. See Table 1 for exact sample descriptions. Lithologic data from Rea (1993).

mas, resulting in more radiogenic ${ }^{207} \mathrm{~Pb} /{ }^{204} \mathrm{~Pb}$ and ${ }^{208} \mathrm{~Pb} /{ }^{204} \mathrm{~Pb}$ ratios for a given ${ }^{206} \mathrm{~Pb} /{ }^{204} \mathrm{~Pb}$ ratio relative to MORB. For example, the Aleutian $\mathrm{Pb}$ isotope ratios clearly plot both within and above the MORB field (Fig. 3). Using a simple two-component mixing calculation, Kay et al. (1978) and Sun (1980) estimated the amount of sediment required to produce a shift in the $\mathrm{Pb}$ isotope ratios of a MORB source to reflect the range observed in the Aleutian arc to be approximately $2 \%$.

The ODP North Pacific sediments have elevated ${ }^{207} \mathrm{~Pb} /{ }^{204} \mathrm{~Pb}$ and ${ }^{208} \mathrm{~Pb} /{ }^{204} \mathrm{~Pb}$ ratio for a given ${ }^{206} \mathrm{~Pb} /{ }^{204} \mathrm{~Pb}$ ratio, plotting well above the MORB field. If previously subducted sediment were mixed into the overlying mantle wedge beneath the Kamchatkan arc (assumed to have a Pacific MORB $\mathrm{Pb}$ isotope signature), the $\mathrm{Pb}$ isotope ratio of the erupted Klyuchevskoy lavas should lie somewhere between the two end-member components (MORB and North Pacific sediments). 

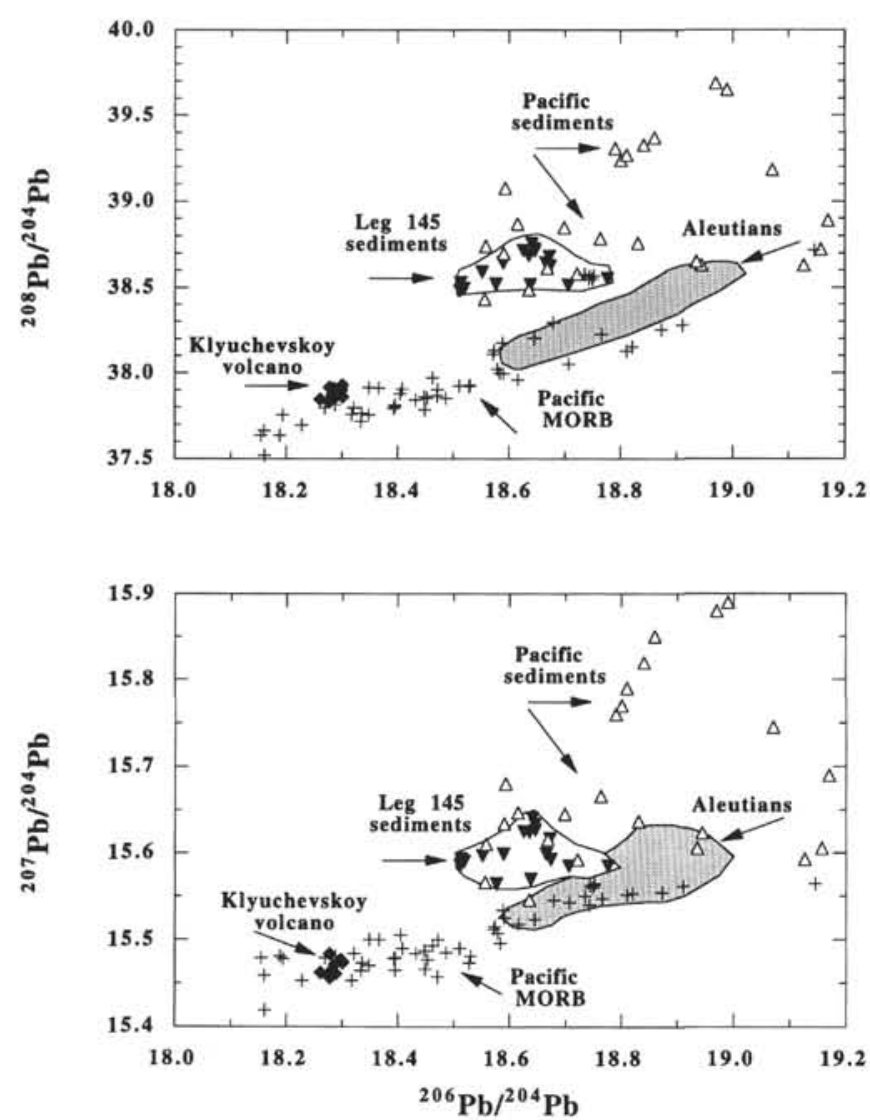

Figure 3. Plot of ${ }^{207} \mathrm{~Pb} /{ }^{204} \mathrm{~Pb}$ and ${ }^{208} \mathrm{~Pb} /{ }^{204} \mathrm{~Pb}$ vs. ${ }^{206} \mathrm{~Pb} /{ }^{204} \mathrm{~Pb}$ isotope ratios for Leg 145 sediments. Other $\mathrm{Pb}$ isotope data are shown for comparison: Pacific sediments not from Leg 145 (Chow and Patterson, 1962; Kay et al. 1978; Ben Othman et al., 1989; McDermott and Hawkesworth, 1991); Klyuchevskoy volcano (Kersting and Arculus, in press); Aleutians (Kay et al., 1978; Morris and Hart, 1983; Meyers and Marsh, 1987); and Pacific MORB (White et al., 1987).

This is not observed. In contrast to the Aleutian data, the entire erupted Klyuchevskoy suite plots within the Pacific MORB field. If the Klyuchevskoy lavas resulted from a continuous mixture of sediment and MORB-type mantle, they should plot along a linear mixing line, but instead they have a narrow, isotopically homogenous range with respect to $\mathrm{Pb}$. Even a small percentage of sediment in the source of the Klyuchevskoy lavas would shift the $\mathrm{Pb}$ isotope ratios away from the MORB field toward the sediment values.

Any simple mass-balance calculation used to calculate the amount of sediment involved in the Kamchatkan arc is hindered by the inability to assess accurately the $\mathrm{Pb}$ isotope ratio of the mantle wedge beneath the Kamchatkan arc. Because of the large variation in $\mathrm{Pb}$ isotope ratios for Pacific MORB (see range of values plotted in Fig. 3), there is no meaningful way to choose one $\mathrm{Pb}$ isotope ratio that is representative of MORB. Woodhead and Fraser (1985) used a ${ }^{207} \mathrm{~Pb} /{ }^{204} \mathrm{~Pb}$ ratio of 15.505, and White and Dupré (1986) used 15.5 as the average mantlewedge value in two-component mixing calculations between sediment and mantle. Both $\mathrm{Pb}$ isotope ratios chosen as representative values of MORB are more radiogenic than any of the Klyuchevskoy lavas. Additional shortcomings of this type of calculation are that island-arc slab/mantle interactions are undoubtedly complicated by elemental fractionation caused by dehydration and/or partial melting reactions.

If $\mathrm{Pb}$ is partitioned into the fluid phase during the dehydration of the sediments, it is reasonable that the ascending fluids would contribute a radiogenic $\mathrm{Pb}$ signature to the Klyuchevskoy source. As this is not reflected in the Klyuchevskoy basalts, it is unlikely that either a Pb-bearing fluid or melt from the subducted sediments contributes to the Klyuchevskoy source. Kersting and Arculus (in press) con- cluded that the major source for the Klyuchevskoy magmas is the depleted mantle wedge, with a fluid flux resulting from the dehydration of altered, basaltic oceanic crust, imparting a high ${ }^{87} \mathrm{Sr} /{ }^{86} \mathrm{Sr}$ ratio (from seawater interaction) coupled with a relatively unradiogenic mantle $\mathrm{Pb}$ composition.

Volcanic rocks from several Quaternary volcanoes in Kamchatka were analyzed for ${ }^{10} \mathrm{Be}$ (Tera et al., 1990, 1993). No elevated ${ }^{10} \mathrm{Be}$ concentrations relative to MORB were measured for the Kamchatka volcanic rocks. These data are consistent with the absence of sediments in the source of the Kamchatkan magmas. Other possible explanations include (1) the residence time between subduction and melt extraction is greater than can be traced using ${ }^{10} \mathrm{Be}(\approx 10 \mathrm{~m} . \mathrm{y}$.), (2) young sediments, containing the majority of the ${ }^{10} \mathrm{Be}$, were scraped off and only older sediments were incorporated into the source, and (3) no sediments are entering the Kamchatkan trench. The rate of subduction beneath Kamchatka is rapid $(8.8 \mathrm{~cm} / \mathrm{yr}$; Minster and Jordan, 1978) and therefore, it is most unlikely that the recycling time from subduction to melt extraction to eruption would be greater than $10 \mathrm{~m}$.y. If only the older sediments were subducted and incorporated in the magma source beneath Kamchatka, they would still impart a radiogenic $\mathrm{Pb}$ isotope signature detectable in the erupted Klyuchevskoy lavas, and this is not observed. It is possible that sediments are offscraped or underplated and not subducted to great depths. Abundant evidence of sediment subduction has been demonstrated for island arcs worldwide (von Huene and Scholl, 1991). Although the sediment column in the northernmost end of the Kamchatkan arc is greater than the worldwide average of 400 to $600 \mathrm{~m}$, von Huene and Scholl (1991) estimate that even at trenches where large accretionary prisms form approximately $70 \%$ of the available sediments are subducted. The most consistent interpretation for the observations of (1) radiogenic $\mathrm{Pb}$ ratios of North Pacific sediments relative to MORB, (2) Klyuchevskoy lavas having similar $\mathrm{Pb}$ isotope ratios to MORB, and (3) the lack of a ${ }^{10} \mathrm{Be}$ anomaly in several Quaternary Kamchatka volcanoes is that the subducted sediments are not incorporated into the source of the Klyuchevskoy magmas, and are thus not required for magmagenesis.

\section{Implications for Other Island Ares}

The presence of elevated ${ }^{10} \mathrm{Be}$ concentrations and $\mathrm{Pb}$ isotope ratios in island arcs such as the Aleutians (see Fig. 3) has been interpreted as evidence for sediment involvement in the source of these arc magmas (e.g., Kay et al., 1978; Morris and Tera, 1989). Yet in Kamchatka, there is no $\mathrm{Pb}$ or $\mathrm{Be}$ isotope evidence for the incorporation of sediments into the source of the Klyuchevskoy magmas. Clearly, no single generalized model is adequate to explain both the apparent lack of sediments involved in the source magmas beneath Klyuchevskoy, Kamchatka, and the inferred incorporation of sediments in the Aleutian and Kurile arc magmas.

Whether or not sediments are offscraped, incorporated into the source regions of arc magmas, or carried farther into the deep mantle is determined by a complex interplay of critical parameters such as the age of the subducting crust, rate and angle of subduction, and depth to the Wadati-Benioff zone. The extent by which sediments chemically influence arc magmagenesis or deep-mantle heterogeneity will vary from arc to arc reflecting real differences between geodynamical constraints that ultimately influence melting and dehydration reactions occurring between the slab/mantle interface. The contrasting behavior of subducted sediments in different island arcs points out the need to look for unique features in individual arcs rather than relying solely on similarities in order to govern our understanding of the major factors controlling arc evolution.

\section{ACKNOWLEDGMENTS}

This work was performed under the auspices of the U.S. Department of Energy by Lawrence Livermore National Laboratory under contract no. W-7405-Eng-48. The author extends her gratitude to the 
shipboard scientists, technicians, and crew of the JOIDES Resolution for their successful drilling efforts during Leg 145, which made this study possible. This manuscript benefited from the perceptive reviews of T. Plank and B. Cousens. Special thanks to D.K. Rea and R.J. Arculus for their initial enthusiasm for this project.

\section{REFERENCES*}

Arculus, R.J., Davidson, J.P., Halliday, A.N., Kersting, A.B., Valley, J.W., Okrugin, V.M., Khrenov, A.P., and Fedotov, S.A., in press. The Geochemistry of the World's Most Active Volcano: Kamchatka, Russia (Klyuchevskoy).

Arculus, R.J., and Johnson, R.W., 1978. Criticism of generalized models for the magmatic evolution of arc-trench systems. Earth Planet. Sci. Lett., 39:118-126.

Arculus, R.J., and Powell, R., 1986. Source component mixing in the regions of arc magma generation. J. Geophys. Res., 91:5913-5926.

Armstrong, R.L., 1968. A model for $\mathrm{Sr}$ and $\mathrm{Pb}$ isotopic evolution in a dynamic earth. Rev. Geophys., 6:175-191.

_ 1971. Isotopic and chemical constraints on models of magma genesis in volcanic arcs. Earth Planet. Sci. Lett., 12:137-142.

Becker, H., and Altherr, R., 1992. Evidence from ultra-high-pressure marbles for recycling of sediments into the mantle. Nature, 358:745-748.

Ben Othman, D., White, W.M., and Patchett, J., 1989. The geochemistry of marine sediments, island arc magma genesis, and crust-mantle recycling. Earth Planet. Sci. Lett., 94:1-21.

Brown, L., Klein, J., Middleton, R., Sacks, I.S., and Tera, F., $1982 .{ }^{10} \mathrm{Be}$ in islandarc volcanoes and implications for subduction. Nature, 299:718-720.

Chow, T.J., and Patterson, C.C., 1962. On the occurrence and significance of lead isotopes in pelagic sediments. Geochim. Cosmochim. Acta, 26:263-308.

Coats, R.R., 1962. Magma type and crustal structure in the Aleutian arc. In Macdonald, G.A., and Kuno, H. (Eds.), The Crust of the Pacific Basin. Geophys. Monogr., Am. Geophys. Union, 6:92-109.

Crawford, A.J., Falloon, T.J., and Eggins, S., 1987. The origin of island arc high-alumina basalts. Contrib. Mineral. Petrol., 97:417-430.

Davidson, J.P., 1983. Lesser Antilles isotopic evidence of the role of subducted sediment in island arc magma genesis. Nature, 306:253-256.

Davies, G.R., Nixon, P.H., Pearson, D.G., and Obata, M., 1993. Tectonic implications of graphitized diamonds from the Ronda peridotite massif, southern Spain. Geology, 21:471-474.

Gill, J.B., 1981. Orogenic Andesites and Plate Tectonics: New York (SpringerVerlag).

Gilluly, J., Reed, J.C., and Cady, W.M., 1970. Sedimentary volumes and their significance. Geol. Soc. Am. Bull., 81:353-376.

Hawkesworth, C.J., Hergt, J.M., Ellam, R.M., and McDermott, F., 1991. Element fluxes associated with subduction related magmatism. Philos. Trans. R. Soc. London A, 335:393-405.

Hofmann, A.W., Jochum, K.P., Seufert, M., and White, W.M., 1986. Nb and $\mathrm{Pb}$ in oceanic basalts: new constraints on mantle evolution. Earth Planet. Sci. Lett., 79:33-45.

Hussong, D.M., and Wipperman, L.K., 1981. Vertical movement and tectonic erosion of the continental wall of the Peru-Chile Trench near $11^{\circ} 30^{\prime} \mathrm{S}$ latitude. In Kulm, L.D., Dymond, J., Dasch, E.J., and Hussong, D.M. (Eds.), Nazca Plate: Crustal Formation and Andean Convergence. Mem.-Geol. Soc. Am., 154:509-524.

Ito, E., and Stern, F.J., 1985. Oxygen and strontium isotopic investigations of subduction zone volcanism: the case of the Volcano arc and the Marianas Island arc. Earth Planet. Sci. Lett., 76:312-320.

Jarrard, R.D., 1986. Relations among subduction parameters. Rev. Geophys., 24:217-284.

Kay, R.W., 1980. Volcanic arc magmas: implications of a melting-mixing model for element recycling in the crust-upper mantle system. J. Geol., $88: 497-522$.

Kay, R.W., Sun, S.-S., and Lee-Hu, C.-N., 1978. Pb and Sr isotopes in volcanic rocks from the Aleutian Islands and Pribilof Islands, Alaska. Geochim. Cosmochim. Acta, 42:263-273.

Kersting, A.B., and Arculus, R.J., 1994. Klyuchevskoy volcano, Kamchatka, Russia: the role of high-flux, recharged, tapped and fractionated magma

\footnotetext{
-Abbreviations for names of organizations and publications in ODP reference lists follow the style given in Chemical Abstracts Service Source Index (published by American Chemical Society).
}

chamber(s) in the genesis of high- $\mathrm{Al}_{2} \mathrm{O}_{3}$ from high-MgO basalt. J. Petrol., 35:1-42.

- in press. $\mathrm{Pb}$ isotope composition of Klyuchevskoy volcano, Kamchatka and North Pacific sediments: implications for magmagenesis and crustal recycling in the Kamchatkan Arc. Earth Planet. Sci. Lett.

Lin, P.-N., 1992. Trace element and isotopic characteristics of western Pacific pelagic sediments: implications for the petrogenesis of Mariana arc magmas. Geochim. Cosmochim. Acta, 56:1641-1654.

Marsh, B.D., 1982. On the mechanics of igneous diapirism, stoping, and zone melting. Am. J. Sci., 282:808-855.

McDermott, F., and Hawkesworth, C.J., 1991. Th, Pb, and Sr isotope variations in young island arc volcanics and oceanic sediments. Earth Planet. Sci. Lett., 104:1-15.

Meijer, A., 1976. Pb and Sr isotopic data bearing on the origin of volcanic rocks from the Mariana island-arc system. Geol. Soc. Am. Bull., 87:1358-1369.

Meyers, J.D., and Marsh, B.D., 1987. Aleutian lead isotopic data: additional evidence for the evolution of lithospheric plumbing systems. Geochim. Cosmochim. Acta, 51:1833-1842.

Meyers, J.D., Marsh, B.D, and Sinha, A.K., 1985. Strontium isotopic and selected trace element variations between two Aleutian volcanic centers (Adak and Atka): implications for the development of arc volcanic plumbing systems. Contrib. Mineral. Petrol., 91:221-234.

Minster, J.B., and Jordan, T.H., 1978. Present-day plate motions. J. Geophys. Res., 83:5331-5354.

Morris, J.D., and Hart, S.R., 1983. Isotopic and incompatible element constraints on the genesis of island arc volcanics from Cold Bay and Amak islands, Aleutians, and implications for mantle structure. Geochim. Cosmochim. Acta, 47:2015-2030.

Morris, J.D., and Tera, F., 1989. ${ }^{10} \mathrm{Be}$ and ${ }^{9} \mathrm{Be}$ in mineral separates and whole rocks from volcanic arcs: implications for sediment subduction. Geochim. Cosmochim. Acta, 53:3197-3206.

Nicholls, I.A., and Ringwood, A.E., 1973. Effects of water on olivine stability in tholeiite and the production of silica-saturated magmas in the island-arc environment. J. Geol., 81:285-300.

Nimz, G.J., Cameron, K.L., and Niemeyer, S., 1993. The La Olivina pyroxenite suite and the isotopic compositions of mantle basalts parental to the mid-Cenozoic arc volcanism of northern Mexico. J. Geophy. Res., 98:6489-6509.

Oversby, V.M., and Ewart, A., 1972. Lead isotopic compositions of TongaKermadec volcanics and their petrogenetic significance. Contrib. Mineral. Petrol., 37:181-210.

Pearson, D.G., Davies, G.R., and Nixon, P.H., 1993. Geochemical constraints on the petrogenesis of diamond facies pyroxenites from the Beni Bousera peridotite massif, north Morocco. J. Petrol., 34:125-172.

Perfit, M.R., Gust, D.A., Bence, A.E., Arculus, R.J., and Taylor, S.R., 1980. Chemical characteristics of island-arc basalts: implications for mantle sources. Chem. Geol., 30:227-256.

Plank, T., and Langmuir, C.H., 1993. Tracing trace elements from sediment input to volcanic output at subduction zones. Nature, 362:739-743.

Rea, D.K., 1993. Paleoceanographic record of North Pacific quantified. Eos, $74: 406-411$

Ryan, J.G., and Langmuir, C.H., 1988. Beryllium systematics in young volcanic rocks: implications for ${ }^{10} \mathrm{Be}$. Geochim. Cosmochim. Acta, 52:237244.

Scholl, D.W., and Creager, J.S., 1973. Geologic synthesis of Leg 19 (DSDP) results: far North Pacific and Aleutian Ridge, and Bering Sea. In Creager, J.S., Scholl, D.W., et al., Init. Repts. DSDP, 19: Washington (U.S. Govt. Printing Office), 897-913.

Sun, S.-S., 1980. Lead isotopic study of young volcanic rocks from mid-ocean ridges, ocean islands and island arcs. Philos. Trans. R. Soc. London A, 297:409-445.

Tatsumi, Y., Murasaki, M., Arsadi, E.M., and Nohda, S., 1991. Geochemistry of Quaternary lavas from NE Sulawesi: transfer of subduction components into the mantle wedge. Contrib. Mineral. Petrol., 107:137-149.

Tatsumoto, M., 1978. Isotopic composition of lead in oceanic basalt and its implication to mantle evolution. Earth Planet. Sci. Lett., 38:63-87.

Tatsumoto, M., and Knight, R.J., 1969. Isotopic composition of lead in volcanic rocks from central Honshu - with regard to basalt genesis. Geochem. J., 3:53-86.

Tera, F., Brown, L., Morris, J., Sacks, I.S., Klein, J., and Middleton, R., 1986. Sediment incorporation in island-arc magmas: inferences from ${ }^{10} \mathrm{Be}$. Geochim. Cosmochim. Acta, 50:535-550.

Tera, F., Morris, J., Leeman, W.P., and Tsvetkov, A.A., 1990. Further evidence from Be-B systematics for the homogeneity of the subducted component 
in arc magmatism: case of the Kurile-Kamchatka arc. Int. Conf. Geochron. Canberra, Australia, 7:100. (Abstract)

Tera, F., Morris, J.D., Ryan, J., Leeman, W.P., and Tsvetkov, A.A., 1993. Significance of ${ }^{10} \mathrm{Be}-{ }^{9} \mathrm{Be}$ correlation in lavas of the Kurile-Kamchatka Arc. Eos, 74:674.

Todt, W., Cliff, R.A., Hanser, A., and Hofman, A.W., $1984 .{ }^{202} \mathrm{~Pb}-{ }^{205} \mathrm{~Pb}$ spike for $\mathrm{Pb}$ isotopic analysis. Terra Cognita, 4:209. (Abstract)

von Huene, R., and Scholl, D.W., 1991. Observations at convergent margins concerning sediment subduction, subduction erosion, and the growth of the continental crust. Rev. Geophys., 29:279-316.

White, W.M., and Dupré, B., 1986. Sediment subduction and magma genesis in the Lesser Antilles: isotopic and trace element constraints. J. Geophys. Res., 91:5927-5941.
White, W.M., Hofmann, A.W., and Puchelt, H., 1987. Isotope geochemistry of Pacific mid-ocean ridge basalt. J. Geophys. Res., 92:4881-4893.

Woodhead, J.D., and Fraser, D.G., 1985. Pb, Sr, and ${ }^{10} \mathrm{Be}$ isotopic studies of volcanic rocks from the Northern Mariana Islands: implications for magma genesis and crustal recycling in the western Pacific. Geochim. Cosmochim. Acta, 49:1925-1930.

Date of initial receipt: 4 April 1994

Date of acceptance: 12 August 1994

Ms 145SR-152 